\title{
Emergency Nurses' Experience on End-of-life Care: An Integrative Review
}

\author{
Wai Keung Johnson TSE \\ Accident and Emergency Department \\ Queen Elizabeth Hospital \\ Hong Kong, China \\ johnsontse@hotmail.com
}

\author{
Kam Ki Stanley LAM \\ School of Nursing \\ Tung Wah College \\ Hong Kong, China \\ stanleylam@twc.edu.hk
}

\author{
Shuk Yu Maria HUNG \\ School of Nursing \\ Tung Wah College \\ Hong Kong, China \\ mariahung@twc.edu.hk
}

\begin{abstract}
Emergency nurses are regarded as the key healthcare professional (HCP) in the emergency department endof-life (ED-EOL) care. The emergency nurses encountered the dying and death on a regular base. Still, they find the EOL care is another aspect and caring from their usual practice. With the successful ED-EOL care delivery, it can help to meet the needs of the imminent patients and families. Emergency nurses admired the pain and symptoms management helping the ED-EOL patients. This paper reviewed the existing literature on the emergency nurses' perception of ED-EOL care. A systematic search of the literature published between January 2005 and January 2016 was conducted to identify published studies concerning emergency nurses' practice and the influencing factors in EOL care provision. The final sample for this integrative review was comprised of 23 studies. It is suggested in the results of the included studies that emergency nurses' EOL care in the clinical context could involve the care of the dying patients and their families in both physical, psychosocial and spiritual aspects. Further study of the emergency nurses and different ED-HCPs are encouraged which could make the ED-EOL care more fruitful and bright in the future.
\end{abstract}

Keywords-end of life care; emergency nurses; emergency nursing

\section{INTRODUCTION}

The emergency departments are often cited as a setting which emphasizes the provision of urgent treatment and critical care [1]. Alongside with the nature of the care, the emergency departments are also considered as a destination which indicates the dying of patients with the fatal condition [2]. Considering that patients who are terminally ill or near death routinely approaching the end of their life in the emergency care context, the role and position of emergency departments in the involvement of end-of-life (EOL) care are receiving growing attention recently [3]. Similar to the EOL care which is most commonly offered in a palliative setting, the aims of EOL care in an emergency care setting emphasizes the provision of quality care of a dying patient in meeting one's physical, psychosocial, and spiritual needs [4]. Indeed, the implementation of EOL care in the emergency departments serves a pivotal function in offering comfort and holistic care to patients with terminal conditions that emphasizes the facilitation of peaceful and dignified death [5]. It is suggested that high-quality EOL care could relieve the physical suffering of the dying [6]. In addition, appropriate EOL care could also alleviate the emotional distress of the significant others of the dying patients, leading to a significant reduction of incidences of related emotional distress and mood disorder such as depression and anxiety [7]. Also, nurses and other healthcare professionals who are involved in the caring of terminal patients experienced job satisfaction and emotional relief for adequate provision of EOL care [8].

However, implementing EOL care in the emergency care context could be both challenging and demanding to emergency nurses. One of the most frequently cited limiting issues encountered by emergency nurses in implementing EOL care is concerning the constraints of workload, as the provision of EOL care is considered a challenging and demanding task to emergency nurses under the high pressure and high volume workloads in the emergency departments [9]. Additionally, the emergency nurses' awareness, willingness, and ability in providing EOL care could be questionable, as it is reported from various study that emergency nurses are not prepared to participate in EOL care in the emergency care settings, as most of them considered EOL care is beyond their scope of practice in emergency care [4]. Existing evidence also highlighted that a number of emergency nurses were unconfident in offering EOL care to terminally ill patients because of lack of knowledge and skills in EOL care in which they were not technically and psychologically prepared for providing EOL care [9]. While some research has been conducted on the emergency nurses' experiences and perceptions in the provision of EOL care [4], there has been little clear and consistent evidence that addresses the nature of EOL practice in the emergency context and the challenges facing emergency nurses during the implementation of EOL care.

In seeking to address these knowledge gaps, a review of the literature has been undertaken. This integrative review aims to highlight the nature of actual EOL practice in the emergency care context and showcase the factors affecting emergency nurses in providing EOL care in practice. It is believed that the findings of this review would facilitate healthcare institutes to promote EOL care in the emergency care context and enhance 
the awareness of emergency nurses in the implementation of EOL care. The guiding question used in the present integrative review was "what are the tasks and influencing factors included in emergency nurses' EOL care in the clinical context?"

\section{METHODS}

\section{A. Design}

This literature review adopted an integrative approach which was guided by the framework by Whittemore and Knafl [10]. An integrative review is a systematic method in reviewing literature, in which enables the synthesis of findings of empirical studies of diverse research methods [10]. Through integrating existing evidence-based knowledge in the literature, a comprehensive understanding concerning a phenomenon could be achieved; in the present review, the emergency nurses' practice and the influencing factors in the provision of EOL were addressed from existing research in the literature. An integrative review consists of five iterative stages, which include problem identification, literature search, data evaluation, data analysis, and result presentation [10].

\section{B. Search Methods}

A systematic search of the literature published between January 2005 and January 2016 was conducted to identify published studies concerning emergency nurses' practice and the influencing factors in EOL care provision. Keyword searches of four electronic databases, namely CINAHL, MEDLINE, PsycINFO, and PubMed, were undertaken in January 2016. The search terms used included "accident and emergency department", "emergency department", "emergency room", "emergency nurse", "end of life", "dying”, "palliative care", and "terminal care". Studies were included if they: (1) were published in English from 2005 to 2016, (2) identified emergency nurses as the target population, and (3) focused on the EOL care or care of dying patients. Studies that were not published in peer-reviewed journals were excluded. Disagreements on eligibility were discussed among the first, second, and third authors (JWKT, MSYH, SKKL) to reach consensus. The initial search of the databases generated 275 studies. After assessing the abstract, 98 studies were considered not meeting the inclusion criteria and were excluded. This resulted in the identification of 177 studies. The full-text of these 177 studies were examined for relevance. Of the 177 studies, 154 studies were rejected after assessing the full-text because of ineligibility. The remaining 23 studies were identified to have fulfilled the eligibility and suitable for the present integrative review. Thus, the final sample for this integrative review was comprised of 23 studies. The process of literature searching and selection of studies is outlined in Figure 1.

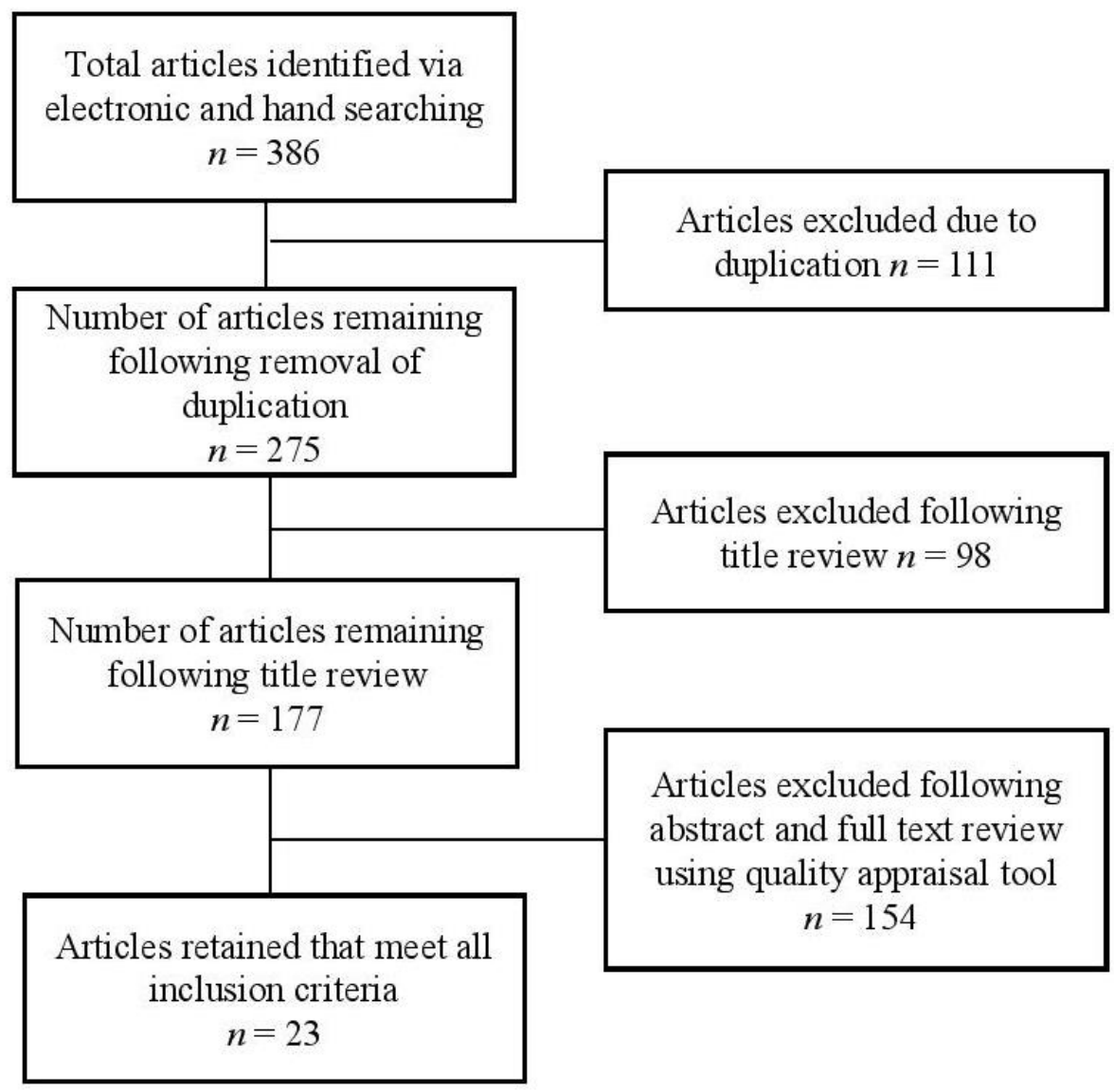

Figure 1. The process of literature searching and selection of studies 


\section{Qualitative Evaluation}

Once the studies were identified, the quality of evidence of each study was determined by adopting the framework suggested by Stetler et al. [11]. Accordingly, the quality of evidence of a study could be classified into six levels which depends on the sources of evidence: level I, meta-analysis of controlled studies; level II, experimental studies; level III, quasi-experimental studies; level IV, non-experimental studies, level $\mathrm{V}$, case report and program evaluation, and level VI, expert opinions. In this scoring scheme, level I represents the highest rating of the quality of evidence while level VI represents the lowest [11]. The levels of evidence of the included studies are included in Table 1.

\section{Data Abstraction and Synthesis}

The included studies were examined and analyzed through systematic comparison of selected matrices based on the recommendation by Ursi and Galvão [12], in which the following data categories are identified: (1) authors; (2) publication year; (3) country; (4) aims; (5) study design; (6) sample characteristics; (7) key findings; and (8) level of evidence according to Stetler et al. [11]. A synthesis of the studies included in this integrative review is displayed in Table 1 .

\section{RESULTS}

Twenty-three studies were identified and included in the present integrative review. Of the 23 studies, 11 (47.8\%) studies adopted a qualitative design, $11(47.8 \%)$ studies adopted a quantitative design, and $1(4.4 \%)$ adopted a mixed method. All the 23 studies presented quality of evidence of level IV. The summaries of the studies is included in Table 1. It is suggested in the results of the included studies that emergency nurses' EOL care in the clinical context could involve the care of the dying patients and their families in both physical, psychosocial, and spiritual aspects. In addition, various factors could intervene emergency nurses' practice of EOL care, which included time and environment constraints, communication among HCPs as well as patients and families, nurses' attitudes towards EOL care, and supports for colleagues and patients' families. The results of the studies are summarized in Table 1 with references number 13-35.

\section{DISCUSSION}

\section{A. Tasks Included in Emergency Nurses' EOL-Care in the Clinical Context}

The Death in ED is an unwelcome event [13]. Emergency nurses tackle the different situation of dying in ED every day. Bailey et al. [14] mentioned two trajectories of death and EOL situation happening in ED. 'Spectacular' described the EOL care for sudden death, usually traumatic injuries and death. 'Subtacular' described the EOL care in ED for those dying pattern which needs more on the symptoms and pain management of their terminal or chronic illness, and these patients were usually treated and put in the lower priority in ED.
This was due to needless of higher-level attention and interventions by compared to the 'spectacular' group. Some papers discussed how the emergency nurses perceive the EOL patients with 'subtacular' dying [13, 20, 26, 30, 32]. Only one article [25] among the searched literature discussed on the emergency nurses' perception towards the 'spectacular' EDEOL care.

In addition to the actual care of the death of the patients, comfort and care and symptom control is another main component of EOL care by the emergency nurses. Chan [20] stated that heroic interventions and treatments are no longer useful and necessary for the EOL patients in the busy, pushy and fast-paced ED environment. Since the death is imminent, treatment for the EOL patients should be no longer invasive and aggressive. Treatment should focus on comfort care, symptoms and pain management for these patients during the EOL stage $[20,25,30,32]$. Although some emergency department healthcare professionals (ED-HCP) commented ED is not an ideal place and not a flavor for EOL dying, [13, 15, 35] studies of Shearer et al. [31] and Jelinek et al. [26] reflected the emergency nurses' admiration on the comfort care, they delivered.

ED-EOL patients' physical condition might not be able for them to communicate with the families and HCPs. Still, the cares of their emotion, psychosocial and spirituals care should not be neglected [26, 30]. Emergency nurses regarded themselves as the key HCP to care the EOL dying patient $[18,20]$. They agreed that more interventions should be invested and focused on the psychosocial and spiritual care of the EOL dying patients, as well as their families [19, 20]. Moreover, the issue of dignified dying for the EOL patients in ED also alerted the emergency nurses. Emergency nurses commented the wish of patients' on Do Not Active Resuscitative (DNAR) or the advanced care planning (ACP) were always being neglected by the families, and sometimes even the HCPs $[22,32]$. This could be due to the concerns on the legal aspects of advance divertive for EOL patients. On the other hand, Bailey et al. $[14,15]$ commented the usual ED setting is leaving and isolating the EOL patients to another corner in ED, which was not easily approached and being overlooked. Emergency nurses commented dignified dying is always being neglected by the emergency HCP [20, 21, 32]. A silent and respectful place for the EOL patients, and allowing the families to stay with for final farewell is an essential element in 'good death' [21].

On top of caring the patients who are approaching the end of their life, emergency nurses were reportedly engaged in caring for the families of the dying patients. Emergency nurses' perceptions on the families and the care-givers of EOL patients was discussed among the literature [19, 23, 25]. A study carried by Smith et al. [32] concluded how the ED-HCPs connected with families of EOL patients. One important issue mentioned that the families are distressed by the EOL symptoms and the prognosis of their beloved family member. However, perceptions of emergency nurses on the families' needs of psychosocial and spiritual cares were always be neglected and not widely studied [26, 27, 30]. 
Table 1. A synthesis of the studies included in the integrative review

\begin{tabular}{|c|c|c|c|c|c|c|c|}
\hline $\begin{array}{l}\text { Reference } \\
\text { number }\end{array}$ & $\begin{array}{l}\text { Author(s) } \\
\text { and Year }\end{array}$ & $\begin{array}{l}\text { Country/ } \\
\text { Region }\end{array}$ & Study aims & $\begin{array}{c}\text { Sample } \\
\text { and Setting }\end{array}$ & $\begin{array}{c}\text { Design } \\
\text { and Methods }\end{array}$ & Key findings & $\begin{array}{c}\text { Quality } \\
\text { of } \\
\text { evidence }\end{array}$ \\
\hline 13 & $\begin{array}{l}\text { Bailey et } \\
\text { al., 2011a }\end{array}$ & $\begin{array}{c}\text { United } \\
\text { Kingdom }\end{array}$ & $\begin{array}{l}\text { Explore EOL care in the } \\
\text { ED and provide an } \\
\text { understanding of how } \\
\text { care is delivered to the } \\
\text { dying, deceased and } \\
\text { bereaved in the } \\
\text { emergency setting }\end{array}$ & $\begin{array}{l}28 \text { participants. } \\
\text { Observational study } \\
\text { with a semi- } \\
\text { structured interview } \\
\text { (10 ED nurses) in a } \\
\text { large ED in the UK }\end{array}$ & $\begin{array}{l}\text { Qualitative } \\
\text { ethnographic } \\
\text { study. Over } 900 \\
\text { hours of field } \\
\text { observations over } \\
12 \text { months with an } \\
\text { in-depth interview }\end{array}$ & $\begin{array}{l}\text { Identified the issue of ED-EOL: environment affects } \\
\text { the level of attention patients, and families receive in } \\
\text { the ED; staff perceive to hide the EOL through the } \\
\text { segregation of the dying and bereaved; poor care due to } \\
\text { segregation in the ED; death is perceived as not ED } \\
\text { business and the setting that is more positively } \\
\text { associated with saving life; nurse is placed to improve } \\
\text { the quality of EOL in ED }\end{array}$ & level IV \\
\hline 14 & $\begin{array}{l}\text { Bailey et } \\
\text { al., } 2011 \mathrm{~b}\end{array}$ & $\begin{array}{c}\text { United } \\
\text { Kingdom }\end{array}$ & $\begin{array}{l}\text { Explore how ED nurses } \\
\text { manage the emotional } \\
\text { impact of death and } \\
\text { dying in emergency } \\
\text { work and present a } \\
\text { model for developing } \\
\text { expertise in EOL care } \\
\text { delivery }\end{array}$ & $\begin{array}{l}28 \text { participants. } \\
\text { Observational study } \\
\text { with a semi- } \\
\text { structured interview } \\
\text { (10 ED nurses) in a } \\
\text { large ED in the UK }\end{array}$ & $\begin{array}{l}\text { Qualitative } \\
\text { ethnographic } \\
\text { study. Over } 900 \\
\text { hours of field } \\
\text { observations over } \\
12 \text { months with an } \\
\text { in-depth interview }\end{array}$ & $\begin{array}{l}\text { Identified that ED nurses perceived deliver end-of-life } \\
\text { care by going through three stages of development: } \\
\text { investment of the self in the nurse-patient relationship; } \\
\text { management of emotional labor; development of } \\
\text { emotional intelligence }\end{array}$ & level IV \\
\hline 15 & $\begin{array}{l}\text { Bailey et } \\
\text { al., 2011c }\end{array}$ & $\begin{array}{c}\text { United } \\
\text { Kingdom }\end{array}$ & $\begin{array}{l}\text { Explore EOL care in the } \\
\text { ED and provide an } \\
\text { understanding of how } \\
\text { care is delivered to the } \\
\text { dying, deceased and } \\
\text { bereaved in the } \\
\text { emergency setting }\end{array}$ & $\begin{array}{l}28 \text { participants. } \\
\text { Observational study } \\
\text { with a semi- } \\
\text { structured interview } \\
\text { (10 ED nurses) in a } \\
\text { large ED in the UK }\end{array}$ & $\begin{array}{l}\text { Qualitative } \\
\text { ethnographic } \\
\text { study. Over } 900 \\
\text { hours of field } \\
\text { observations over } \\
12 \text { months with an } \\
\text { in-depth interview }\end{array}$ & $\begin{array}{l}\text { Identified } 2 \text { trajectories of EOL care were in ED: } \\
\text { spectacular and subtacular. Patients and family } \\
\text { members experienced EOL care in ED have distinctly } \\
\text { different care as the argue of these } 2 \text { trajectories, } \\
\text { induced dissatisfaction for ED staff and distress and } \\
\text { frustration }\end{array}$ & level IV \\
\hline 16 & $\begin{array}{l}\text { Beckstrand } \\
\text { et al., } \\
2012 \mathrm{a}\end{array}$ & $\begin{array}{l}\text { United } \\
\text { States }\end{array}$ & $\begin{array}{l}\text { Investigate the size, } \\
\text { frequency, and } \\
\text { magnitude of obstacles } \\
\text { in providing EOL care } \\
\text { in rural emergency } \\
\text { departments as } \\
\text { perceived by rural } \\
\text { emergency nurses }\end{array}$ & $\begin{array}{l}\text { 236:508 emergency } \\
\text { nurses from } 52 \text { rural } \\
\text { hospitals in Idaho, } \\
\text { Wyoming, Utah, } \\
\text { Nevada, and Alaska }\end{array}$ & $\begin{array}{l}\text { 57-item } \\
\text { questionnaires }\end{array}$ & $\begin{array}{l}\text { Identified } 3 \text { obstacles: family and friends who } \\
\text { continually call the nurse for an update on the patients' } \\
\text { condition rather than calling the designated family } \\
\text { member; knowing the patient or family member } \\
\text { personally; poor design of emergency department that } \\
\text { does not allow for privacy of dying patients or grieving } \\
\text { family members }\end{array}$ & level IV \\
\hline 17 & $\begin{array}{l}\text { Beckstrand } \\
\text { et al., } \\
2012 \mathrm{~b}\end{array}$ & $\begin{array}{l}\text { United } \\
\text { States }\end{array}$ & $\begin{array}{l}\text { Determine the impact of } \\
\text { ED design on EOL care } \\
\text { as perceived by the } \\
\text { nurses and to determine } \\
\text { how much nurses have } \\
\text { on the design of their } \\
\text { ED }\end{array}$ & $\begin{array}{l}\text { 215:500 emergency } \\
\text { nurses who were a } \\
\text { member of ENA }\end{array}$ & $\begin{array}{l}\text { 25-item } \\
\text { questionnaire }\end{array}$ & $\begin{array}{l}\text { No concluded that ED design was as large an obstacle } \\
\text { to EOL care as previous studies; ED design helped } \\
\text { EOL care at a great rate than it obstructed EOL care; } \\
\text { nurses have little impact to design or layout changes; } \\
\text { request for designing a private place for grieved } \\
\text { families }\end{array}$ & level IV \\
\hline
\end{tabular}




\begin{tabular}{|c|c|c|c|c|c|c|c|}
\hline 18 & $\begin{array}{l}\text { Beckstrand } \\
\text { et al., } \\
2012 \mathrm{c}\end{array}$ & $\begin{array}{l}\text { United } \\
\text { States }\end{array}$ & $\begin{array}{l}\text { Determine what nurses } \\
\text { suggested for improving } \\
\text { EOL care }\end{array}$ & $\begin{array}{l}441: 1000 \text { emergency } \\
\text { nurses who were } \\
\text { members of ENA }\end{array}$ & $\begin{array}{l}\text { Questionnaire. } 2 \\
\text { phases of the } \\
\text { study }\end{array}$ & $\begin{array}{l}\text { Identified } 5 \text { themes: increasing the amount of time ED } \\
\text { nurses to care; allowing family present during } \\
\text { resuscitation; providing comfortable environment; } \\
\text { providing privacy; providing family grief rooms }\end{array}$ & level IV \\
\hline 19 & $\begin{array}{l}\text { Beckstrand } \\
\text { et al., } 2008\end{array}$ & $\begin{array}{l}\text { United } \\
\text { States }\end{array}$ & $\begin{array}{l}\text { Explore the specific } \\
\text { obstacles impede the } \\
\text { delivery of EOL care in } \\
\text { ED and supportive } \\
\text { behaviors is limited }\end{array}$ & $\begin{array}{l}\text { 384:700 emergency } \\
\text { nurses who were a } \\
\text { member of ENA }\end{array}$ & $\begin{array}{l}\text { 70-item } \\
\text { questionnaire }\end{array}$ & $\begin{array}{l}\text { Identified obstacles: ED nurses are lack of time for } \\
\text { patient care as heavy workload; poor design of ED; } \\
\text { families' misunderstanding of 'life-saving measures.' } \\
\text { Identified supportive behaviors: allowing families time } \\
\text { and environment with the patient after he or she has } \\
\text { died; having good communication between physician } \\
\text { and nurses; providing a peaceful, dignified bedside } \\
\text { scene for bereaved families }\end{array}$ & level IV \\
\hline 20 & $\begin{array}{l}\text { Chan, } \\
2011\end{array}$ & $\begin{array}{l}\text { United } \\
\text { States }\end{array}$ & $\begin{array}{l}\text { Identify different } \\
\text { trajectories of } \\
\text { approaching death in an } \\
\text { effort to describe the } \\
\text { EOL }\end{array}$ & $\begin{array}{l}\text { Observation of } 10 \\
\text { dying patients and } \\
\text { ED staff interaction } \\
\text { ( } 5 \text { ED nurses) with } \\
\text { an in-depth interview } \\
\text { in a level II trauma } \\
\text { center ED in } \\
\text { Northern California }\end{array}$ & $\begin{array}{l}\text { Qualitative } \\
\text { interpretive } \\
\text { phenomenological } \\
\text { approach with } \\
\text { interviews and } \\
\text { observation }\end{array}$ & $\begin{array}{l}\text { Identified } 7 \text { trajectories of approaching death in ED: } \\
\text { dead on arrival; prehospital resuscitation with } \\
\text { subsequent ED death; prehospital resuscitation with } \\
\text { survival until admission; terminally ill and comes to } \\
\text { the ED; frail and hovering near death; alive and } \\
\text { interactive on arrival, but arrests in the ED; potentially } \\
\text { preventable death by omission or commission }\end{array}$ & level IV \\
\hline 21 & $\begin{array}{l}\text { Decker et } \\
\text { al., } 2015\end{array}$ & Australia & $\begin{array}{l}\text { Describe the } \\
\text { experiences of } \\
\text { emergency nurses in } \\
\text { providing end-of-life } \\
\text { care, which is the care } \\
\text { delivered to a patient } \\
\text { during the time directly } \\
\text { preceding death }\end{array}$ & $\begin{array}{l}25 \text { emergency } \\
\text { nurses. Focus group } \\
\text { interview in } 3 \text { EDs } \\
\text { within an Australian } \\
\text { tertiary hospital } \\
\text { network }\end{array}$ & $\begin{array}{l}\text { A qualitative } \\
\text { study with using } \\
\text { grounded theory }\end{array}$ & $\begin{array}{l}\text { Identified } 3 \text { main themes: dying in the ED is not ideal; } \\
\text { strategies to manage death in the ED; Consequences of } \\
\text { death in the ED }\end{array}$ & level IV \\
\hline 22 & $\begin{array}{l}\text { Heaston et } \\
\text { al., } 2006\end{array}$ & $\begin{array}{l}\text { United } \\
\text { States }\end{array}$ & $\begin{array}{l}\text { Determine the } \\
\text { perceived obstacles and } \\
\text { supportive behaviors in } \\
\text { providing ED-EOL care } \\
\text { to the dying }\end{array}$ & $\begin{array}{l}\text { 169: } 700 \text { emergency } \\
\text { nurses who were a } \\
\text { member of ENA }\end{array}$ & $\begin{array}{l}\text { 73-item } \\
\text { questionnaire }\end{array}$ & $\begin{array}{l}\text { Identified greatest obstacles: nurses have a heavy } \\
\text { workload on caring EOL patients; dealing with angry } \\
\text { families; poor design of ED which lacks privacy for } \\
\text { dying patients or grieving family members } \\
\text { Identified supportive behaviors: good communication } \\
\text { with a physician for caring the dying patient; } \\
\text { physicians meeting in person with the families after the } \\
\text { patient's death; ED designed a place for families to } \\
\text { grieve in private }\end{array}$ & level IV \\
\hline 23 & Ho, 2016 & $\begin{array}{l}\text { Hong } \\
\text { Kong }\end{array}$ & $\begin{array}{l}\text { To evaluate the } \\
\text { obstacles and } \\
\text { supportive behaviors to } \\
\text { providing end-of-life } \\
\text { care as perceived by } \\
\text { emergency nurses }\end{array}$ & $\begin{array}{l}\text { 42:68 emergency } \\
\text { nurses from an ED of } \\
\text { a major acute } \\
\text { hospital in Hong } \\
\text { Kong }\end{array}$ & $\begin{array}{l}\text { A quantitative } \\
\text { study with cross- } \\
\text { sectional } \\
\text { descriptive survey }\end{array}$ & $\begin{array}{l}\text { Identified the obstacles and supportive factors for ED- } \\
\text { EOL in the local situation; similar finding to the } \\
\text { previous study }\end{array}$ & level IV \\
\hline 24 & $\begin{array}{l}\text { Jackson, } \\
2010\end{array}$ & $\begin{array}{l}\text { United } \\
\text { Kingdom }\end{array}$ & $\begin{array}{l}\text { To study the EOL care } \\
\text { decision by patients, }\end{array}$ & $\begin{array}{l}151 \text { clinical records } \\
\text { were reviewed. } 70\end{array}$ & $\begin{array}{l}\text { A quantitative } \\
\text { study with in- }\end{array}$ & $\begin{array}{l}\text { Identified the concerns for ED staff on EOL issue: lack } \\
\text { of privacy; the issue of unpredictability; care of }\end{array}$ & level IV \\
\hline
\end{tabular}




\begin{tabular}{|c|c|c|c|c|c|c|c|}
\hline & & & $\begin{array}{l}\text { relatives and care } \\
\text { professionals, and their } \\
\text { perceptions of care } \\
\text { pathway in the last } 48 \\
\text { hour of life }\end{array}$ & $\begin{array}{l}\text { semi-structured } \\
\text { interview of patients } \\
\text { and the families from } \\
\text { a district hospital in } \\
\text { Nuneaton, } \\
\text { Warwickshire }\end{array}$ & $\begin{array}{l}\text { depth interview } \\
\text { and retrospective } \\
\text { record reviews } \\
\text { within } 6 \text { months } \\
\text { audit }\end{array}$ & $\begin{array}{l}\text { bereaved relatives; organizational issue; maintaining } \\
\text { communication; accessing emergency service }\end{array}$ & \\
\hline 25 & $\begin{array}{l}\text { Jacobs et } \\
\text { al., } 2010\end{array}$ & $\begin{array}{l}\text { United } \\
\text { States }\end{array}$ & $\begin{array}{l}\text { Analyze the ED nurses } \\
\text { and physicians of their } \\
\text { preferences for EOL } \\
\text { care in trauma }\end{array}$ & $\begin{array}{l}774 \text { (460 nurses): } \\
1532 \text { healthcare staff } \\
\text { who were members } \\
\text { of Society of Trauma } \\
\text { Nurses }\end{array}$ & $\begin{array}{l}\text { 43-item } \\
\text { questionnaire }\end{array}$ & $\begin{array}{l}\text { Concluded that nurses prefer to have their loved one } \\
\text { undergoing resuscitation in treatment room; both } \\
\text { nurses and physicians agreed withholding life- } \\
\text { sustaining treatment when no hope of recovery; nurses } \\
\text { believe patients have right for treatment goal when } \\
\text { physician think is medically futile }\end{array}$ & level IV \\
\hline 26 & $\begin{array}{l}\text { Jelinek et } \\
\text { al., } 2014\end{array}$ & Australia & $\begin{array}{l}\text { Explore the experience } \\
\text { ED staff caring for an } \\
\text { advanced cancer patient } \\
\text { who presents to the ED; } \\
\text { explore improvement } \\
\text { for the patents receive } \\
\text { from clinicians working } \\
\text { in EM, PC and } \\
\text { oncology }\end{array}$ & $\begin{array}{l}83 \text { participants. } \\
\text { Focus group (52 } \\
\text { nurses) interviews } \\
\text { among multiple } \\
\text { healthcare } \\
\text { institutions on the } \\
\text { ED-EOL provision }\end{array}$ & $\begin{array}{l}\text { The qualitative } \\
\text { exploratory study, } \\
\text { with } \\
\text { supplementary } \\
\text { phone interviews }\end{array}$ & $\begin{array}{l}\text { Identified suggestions on clinical care for patients, the } \\
\text { clinical pathway to facilitate cares, information access } \\
\text { on patients' clinical data and ED staff education on } \\
\text { ED-EOL care }\end{array}$ & level IV \\
\hline 27 & $\begin{array}{l}\text { Jelinek et } \\
\text { al., } 2013\end{array}$ & Australia & $\begin{array}{l}\text { Identify issue important } \\
\text { to an emergency, } \\
\text { palliative care and } \\
\text { oncology clinical staff } \\
\text { in managing people } \\
\text { with advanced cancer } \\
\text { presenting to EDs }\end{array}$ & $\begin{array}{l}83 \text { participants. } \\
\text { Focus group (52 } \\
\text { nurses) interviews } \\
\text { among multiple } \\
\text { healthcare } \\
\text { institutions on the } \\
\text { ED-EOL provision }\end{array}$ & $\begin{array}{l}\text { The qualitative } \\
\text { exploratory study, } \\
\text { with } \\
\text { supplementary } \\
\text { phone interviews }\end{array}$ & $\begin{array}{l}\text { Identified perceptions of the ED-EOL provision on the } \\
\text { issue of physical environment, availability of resource } \\
\text { and roles and expectation of staff EOL provisions }\end{array}$ & level IV \\
\hline 28 & $\begin{array}{l}\text { Lane et al., } \\
\quad 2014\end{array}$ & Australia & $\begin{array}{l}\text { Explore the views and } \\
\text { experience of ED staff } \\
\text { caring for an advanced } \\
\text { cancer patient who } \\
\text { presents to the ED; } \\
\text { explore improvement } \\
\text { for the patents receive } \\
\text { from clinicians working } \\
\text { in EM, PC and } \\
\text { oncology }\end{array}$ & $\begin{array}{l}83 \text { participants. } \\
\text { Focus group (52 } \\
\text { nurses) interviews } \\
\text { among multiple } \\
\text { healthcare } \\
\text { institutions on the } \\
\text { ED-EOL provision }\end{array}$ & $\begin{array}{l}\text { The qualitative } \\
\text { exploratory study, } \\
\text { with } \\
\text { supplementary } \\
\text { phone interviews }\end{array}$ & $\begin{array}{l}\text { Identified that ED-EOL care is a conflict between ideal } \\
\text { care and the realities of practice. Improvement } \\
\text { including communication, decision making, and } \\
\text { understanding among other collaborating healthcare } \\
\text { professionals }\end{array}$ & level IV \\
\hline 29 & $\begin{array}{l}\text { Marck et } \\
\text { al., } 2014\end{array}$ & Australia & $\begin{array}{l}\text { Assess barriers and } \\
\text { enablers to EOL care } \\
\text { for cancer patient as } \\
\text { perceived by Australian } \\
\text { ED staff }\end{array}$ & $\begin{array}{l}681 \text { participants. } \\
\text { ( } 237 \text { nurses) of } \\
\text { members of } \\
\text { Australian College of } \\
\text { Emergency Nursing } \\
\text { whom working in } \\
\text { Australian ED }\end{array}$ & $\begin{array}{l}\text { Cross-sectional } \\
63 \text {-item } \\
\text { questionnaire } \\
\text { online }\end{array}$ & $\begin{array}{l}\text { Identified barriers and supportive for ED-EOL care } \\
\text { based on care of the dying patient; patient and family } \\
\text { understanding; futile medical treatment }\end{array}$ & level IV \\
\hline
\end{tabular}




\begin{tabular}{|c|c|c|c|c|c|c|c|}
\hline 30 & $\begin{array}{c}\text { Russ et al., } \\
2015\end{array}$ & Australia & $\begin{array}{l}\text { Investigate the ED staff } \\
\text { experiences and attitude } \\
\text { towards PC provision in } \\
\text { ED }\end{array}$ & $\begin{array}{l}29: 225 \text { (36 nurses) } \\
\text { from an Australia } \\
\text { metropolitan ED }\end{array}$ & $\begin{array}{l}\text { 66-item } \\
\text { questionnaire }\end{array}$ & $\begin{array}{l}\text { Identified both physicians and nurses perceive similar } \\
\text { idea on PC; ED staff are confident with EOL symptom } \\
\text { management; nurses tend to have nasogastric tube } \\
\text { feeding for ED-EOL patients; education needs for } \\
\text { communication and ethical issue }\end{array}$ & level IV \\
\hline 31 & $\begin{array}{l}\text { Shearer et } \\
\text { al., } 2014\end{array}$ & Australia & $\begin{array}{l}\text { Investigate ED staff } \\
\text { perspectives and needs } \\
\text { of PC provision; assess } \\
\text { staff views about death } \\
\text { and dying, and their } \\
\text { awareness of common } \\
\text { causes of death in } \\
\text { Australia }\end{array}$ & $\begin{array}{l}66: 76 \text { (44 nurses) } \\
\text { from an ED in the } \\
\text { south metropolitan } \\
\text { area of Perth, } \\
\text { Western Australia }\end{array}$ & $\begin{array}{l}\text { Self-reporting } \\
\text { survey of the } \\
\text { mixed method } \\
\text { which Likert-type } \\
\text { scales for } \\
\text { quantitative data } \\
\text { and content } \\
\text { analysis for open- } \\
\text { ended qualitative } \\
\text { data }\end{array}$ & $\begin{array}{l}\text { Most participants agreed on limited knowledge on PC } \\
\text { but confident on symptoms control; emergency nurses } \\
\text { have lower confidence in PC provision; strengthen the } \\
\text { education need for emergency nurses }\end{array}$ & level IV \\
\hline 32 & $\begin{array}{l}\text { Smith et } \\
\text { al., } 2009\end{array}$ & $\begin{array}{l}\text { United } \\
\text { States }\end{array}$ & $\begin{array}{l}\text { Explore the attitudes, } \\
\text { experiences, and beliefs } \\
\text { of emergency providers } \\
\text { about PC in the ED }\end{array}$ & $\begin{array}{l}26 \text { participants. } \\
\text { Focus group } \\
\text { interviews ( } 6 \mathrm{ED} \\
\text { nurses) of an ED in } \\
\text { Boston }\end{array}$ & $\begin{array}{l}\text { A qualitative } \\
\text { study with using } \\
\text { purposive } \\
\text { sampling }\end{array}$ & $\begin{array}{l}\text { Identified the attitudinal and structural barriers: } \\
\text { participants equated PC with EOL; disagree the } \\
\text { feasibility and desirability ED-EOL; frequent and } \\
\text { multiple ED visits of palliative patients as the family } \\
\text { distress of EOL symptoms; lack of communication } \\
\text { between outpatient and ED providers leads to the } \\
\text { undesirable outcome; conflict around withholding life- } \\
\text { prolonging treatment; lack of training in pain } \\
\text { management }\end{array}$ & level IV \\
\hline 33 & $\begin{array}{l}\text { Tse et al., } \\
2016\end{array}$ & $\begin{array}{l}\text { Hong } \\
\text { Kong }\end{array}$ & $\begin{array}{l}\text { Understand emergency } \\
\text { nurses' perceptions on } \\
\text { providing ED-EOL care }\end{array}$ & $\begin{array}{l}16 \text { participants from } \\
\text { a major trauma } \\
\text { center of the acute } \\
\text { hospital }\end{array}$ & $\begin{array}{l}\text { A qualitative } \\
\text { study with a semi- } \\
\text { structured } \\
\text { interview }\end{array}$ & $\begin{array}{l}\text { Identified emergency nurses' perceptions on ED-EOL } \\
\text { towards the patients, families, and staff themselves, the } \\
\text { obstacles and supportive factor for ED-EOL }\end{array}$ & level IV \\
\hline 34 & $\begin{array}{l}\text { Weliand et } \\
\text { al., } 2015\end{array}$ & Australia & $\begin{array}{l}\text { Explore ED staffs' } \\
\text { attitude to the ED } \\
\text { environment when } \\
\text { caring advanced cancer } \\
\text { patients, and how these } \\
\text { attitudes are affected via } \\
\text { the PC service, PC } \\
\text { education, staff type } \\
\text { and patients' issues }\end{array}$ & $\begin{array}{l}\text { 681 participants. } \\
\text { ( } 237 \text { nurses) of } \\
\text { members of } \\
\text { Australian College of } \\
\text { Emergency Nursing } \\
\text { whom working in } \\
\text { Australian ED }\end{array}$ & $\begin{array}{l}\text { Cross-sectional } \\
63 \text {-item } \\
\text { questionnaire } \\
\text { online }\end{array}$ & $\begin{array}{l}\text { Identified that overcrowding noise, lack of time and } \\
\text { privacy as barriers to care; dying patient should be } \\
\text { arranged in private place; inability to provide } \\
\text { undesirable care to an advanced cancer patient in ED; } \\
\text { staff attitude was influenced by the experience }\end{array}$ & level IV \\
\hline 35 & $\begin{array}{l}\text { Weil et al., } \\
2015\end{array}$ & Australia & $\begin{array}{l}\text { Explore the } \\
\text { understanding of PC by } \\
\text { ED staff whom caring } \\
\text { for patients with } \\
\text { advanced cancer } \\
\text { attendants }\end{array}$ & $\begin{array}{l}94 \text { participants. } \\
\text { Focus group ( } 22 \\
\text { nurses) and } \\
\text { individual phone } \\
\text { interview ( } 3 \text { nurses) }\end{array}$ & $\begin{array}{l}\text { Qualitative } \\
\text { exploratory study. } \\
2 \text { phases study }\end{array}$ & $\begin{array}{l}\text { Identified a contradictory understanding of PC, } \\
\text { understanding, and engagement of staff in ED-EOL } \\
\text { and staff perceptions of PC utility practical utility of } \\
\text { PC }\end{array}$ & level IV \\
\hline
\end{tabular}




\section{B. Influencing Factors Included in Emergency Nurses' EOL- Care in the Clinical Context}

In most cases, emergency nurses perceived the time and the environment constrain are the two essential elements which induced barriers for the ED-EOL care. Emergency nurses commented the EOL care is high time-demanding care. However, as the busy and heavy workload in an emergency context, they were lack of time and hardly make enough time to provide good ED-EOL care for the care-receivers [14, 29]. As the key HCP for the ED-EOL care, the heavy workload did not allow them to communicate and educate the EOL patients and families [23, 24, 28]. Moreover, due to the time restraint, the quality of EOL care delivery was being affected, and hardly meet the actual needs of the care-receivers $[17,26]$. Emergency nurses voiced out a better resource and manpower for the ED should be made, which they could fixate on the EOL care. Ideally, one to one ratio would be better, which they believe it could benefit the psychosocial and spiritual cares for the EOL care-receivers greatly $[18,27]$.

Emergency nurses commented the ED environment was not suitable for EOL care. The noisy and buzzing alarms and machines sound around was ruining the EOL patients to rest in comfort, silent and peaceful environment. The crowded environment did not facilitate the families to stay with the EOL patients and final farewell. Moreover, the EOL patients and families' privacy was not well protected in the ED setting. It was because of the lack of single rooms, as well as the separation of cubicles by a curtain. This also hesitates their accompaniments $[17,24,28]$. More spaces and single rooms were urged to separate the EOL patients and families from the unfavorable ED environment. This can encourage the families to stay with the EOL patients, and facilitate their grief and bereavement [22, 29, 33]. Rooms for grief and bereavement should not be neglected for the families after EOL patients dying. With a considerable space, different cultural and religious rituals could be performed to fulfill the religious and spiritual needs of EOL care-receivers $[26,30]$

Different ED-HCPs and emergency nurses would have their own perceptions and experiences on handling the EOL care. The different attitude towards ED-EOL care could induced difficulties on the care. Emergency nurses commented that effective communication is important and essential, which directly affect the ED-EOL care quality [28, 29, 30]. Poor communication with families was a big hurdle for the ED-EOL care and could be incited by the unrealistic of families' wishes and acceptances on EOL care [17, 19]. Working under the stress and busy ED setting, and with expectation and knowledge of EOL care differences, the communication among ED-HCPs could be exasperated [28, 32]. Emergency nurses commented the poor communication between the physicians and emergency nurses could also induce undesirable EOL care planning to meet the needs of the EOL dying patients [17].

Emergency nurses suggested an effective communication could flavor for the ED-EOL care delivery. Good communication between the patients and families, as well as between different HCPs could allow the emergency nurses act as the advocator, and allow exchange and understanding for each other's' needs and expectation $[31,35]$. Predominant counseling skills can allow the emergency nurses to break the bad news breaking, understand the needs of EOL care-receivers, and to exchange and share differences in EOL expectations. It is believed that with mastering these skills, conflicts particularly between the families and ED-HCPs could be eliminated, and could benefit the families' grief and bereavement. Few papers mentioned about the DNAR and ACP for the EOL patients [29, $32,35]$. These ideas should be highly noted during the communication and counseling. As EOL dying process could occur suddenly in the ED, a better acknowledgment of DNAR and ACP between the families and different ED-HCPs could help to make suitable and appropriate planning for the EOL patients. However, this area of study is limited.

The attitude of emergency nurses towards the ED-EOL care could create barriers ED-EOL care delivery. As previously mentioned, the hesitation, unwillingness, and reluctance on EDEOL care could affect care delivery. Emergency nurses suggested debriefing sessions allowing them to ventilate and express their anxiety and worries on the ED-EOL care, especially the sense of failure on EOL patients' dying [28, 35]. It also allows the knowledge and experience sharing among themselves. Although ED-HCPs could have a different perspective towards the ED-EOL care, emergency nurses believe that a supportive atmosphere with good teamwork in ED can contribute the ED-EOL care delivery [22].

Emergency nurses commented the families of EOL patients were generally lacking EOL knowledge, misconception of EOL care and misunderstanding the prognosis of their dying beloved family members. Some families even though unrealistically that the patient could be rescued with the advanced medical technology $[20,21,35]$. They even do not know what they could do for the EOL dying patient [22]. As a result, conflicts could occur between the families and the ED-HCPs. Conflicts on the interventions and decision making for the EOL patients alerted the emergency nurses. The decision on withdrawing interventions or treatment for the families is harsh and uneasy to make. These were influenced by the ethical, legal, moral, religious and cultural background from different families [28, 32], particularly when the EOL patient is in coma or semiconscious. A decision on DNAR and other life-sustaining interventions and treatments usually relied on the families [30, 32]. One example was on the continuity of nasal-gastric tube feeding for EOL patients. The decision of feeding and the amount to feed was also influenced by the families [30], and the decision of withholding or not makes ambivalence for the HCPs.

Some papers mentioned how the emergency nurses perceive their role and position, and their experience in the ED-EOL care. Emergency nurses self-perceive the conflicts among themselves when providing ED-EOL care. The emergency nurses are welltrained on the active resuscitation and life-saving intervention in the traditional emergency nursing scope [16, 17, 18, 19], which ED-EOL care is another scope of nursing. Some emergency nurses commented the care for dying EOL patients should not bet their duty [21] and treat the EOL care as 'dirty duty' [13]. Although this unwillingness of delivering EOL care, emergency nurses agreed to offer the appropriate interventions for EOL patients was still a rewarding experience [14]. This could be explained by their understanding EOL prognosis and the 
ultimate goal of care for the EOL patients, which comfort, psychosocial and spiritual care should be the focus.

Several papers mentioned and discussed the emotional support for the emergency nurses on and after EOL care delivery. What the management of emotion stress occurred among emergency nurses is essential for the ED-EOL care, as it directly affects the quality of the therapeutic relationship between emergency nurses and the care-receivers [24, 28, 32]. Weil et al. [35] and Lane et al. [28] further echoed on this issue. They commented the frustration on the EOL care for dying patient could also due to the cultural factor of a local institution. Also, the emergency nurses' anxiety and feeling of failure on EOL dying could induce psychological burden for them. In addition, the experience of providing EOL care provoked the emergency nurses to self-reflect and strive for the knowledge enhancement, especially on the pain and symptom management $[26,27]$. It is also a valuable chance for the emergency nurses to develop a specialist role in ED-EOL nursing care on communication and counseling skills and remind them the importance of therapeutic relationship in the ED-EOL care [20].

\section{CONCLUSION}

Emergency nurses are regarded as the key HCP in the EDEOL care. This paper reviewed the existing literature on the emergency nurses' perception of ED-EOL care. The emergency nurses encountered the dying and death in a regular base. Still they find the EOL care is another aspect and caring from their usual practice. With the successful ED-EOL care delivery, it can help to meet the needs of the imminent patients and families. Emergency nurses admired the pain and symptoms management helping the ED-EOL patients. However, conflicts between the families frustrate them on the EOL care delivery. They understand the conflicts could be due to the EOL knowledge deficit and misconceptions of the families. Effective communication and counseling should be well mastered. For emergency nurses, conflicts among themselves towards EDEOL feasibility and sustainability under the pushy and busy ED environment and their traditional emergency training.

Majority of the papers focus on the obstacles and barriers, and supportive factors for the ED-EOL care delivery. Emergency nurses concern the shortage of manpower and time for the ED-EOL care. The ED-EOL care is also highly influenced by the structural and attitude factor. Apart from increasing space and environmental enhancement, communication and counseling technique are also essential for improving the ED-EOL care. The literature on the emergency nurses' perspective on ED-EOL care is limited. Majority of the research was carried among Australia, the United Kingdom, and the States, and lack of the other countries. This review allows the brief idea of how the emergency nurses perceive the EDEOL care. Recommendations may be difficult to implement in the undesirable ED setting. Still, the emergency nurses' suggestions are important as a result doing the best for the EOL care-receivers. Further study of the emergency nurses and different ED-HCPs are encouraged which could make the EDEOL care more fruitful and bright in the future.

\section{REFERENCES}

[1] B. Munroe, K. Curtis, M. Murphy, L. Strachan, L and T. Buckley, "HIRAID: an evidence-informed emergency nursing assessment framework," Australasian Emergency Nursing Journal, vol. 18, no. 2, pp. 83-97, 2015.

[2] H. Seow, L. Barbera, R. Pataky, B. Lawson, E. O'Leary, K. Fassbender and R. Sutradhar, "Does increasing home care nursing reduce emergency department visits at the end of life? A population-based cohort study of cancer decedents," Journal of Pain and Symptom Management, vol. 51, no. 2, pp. 204-212, 2016.

[3] C. K. Norton, G. Hobson and E. Kulm, "Palliative and end-of-life care in the emergency department: guidelines for nurses," Journal of Emergency Nursing, vol. 37, no. 3, pp. 240-245, 2010.

[4] R. Forero, G. McDonnell, B. Gallego, S. McCarthy, M. Mohsin, C. Shanley and K. Hillman, K. "A literature review on care at the end-of-life in the emergency department," Emergency Medicine International, vol. 2012, pp. 1-11, 2012.

[5] World Health Organization, Global atlas of palliative care at the end of life, 2014. [Online] Available: http://www.thewhpca.org/resources/global-atlas-on-end-of-life-care. [Accessed February 22, 2015].

[6] A. Brinkman-Stoppelenburg, J. A. Rietjens and A. van der Heide, "The effects of advance care planning on end-of-life care: a systematic review," Palliative Medicine, vol. 28, no. 8, pp. 1000-1025, 2014.

[7] L. Sallnow, H. Richardson, S. A. Murray and A. Kellehear, "The impact of a new public health approach to end-of-life care: a systematic review," Palliative Medicine, vol. 30, no. 3, pp. 200-211, 2016.

[8] T. Vandrevala, K. Samsi, C. Rose, C. Adenrele, C. Barnes and J. Manthorpe, "Perceived needs for support among care home staff providing end of life care for people with dementia: a qualitative study," International Journal of Geriatric Psychiatry, vol. 32, no. 2, pp. 155-163, 2017.

[9] K. Gloss, K, "End of life care in emergency departments: a review of the literature," Emergency Nurses, vol. 25, no. 2, pp. 29-38, 2017.

[10] R. Whittemore and K. Knafl, "The integrative review: updated methodology," Journal of Advanced Nursing, vol. 52, no. 5, pp. 546-553, 2005.

[11] C. B. Stetler, D. Morsi, S. Rucki, S. Broughton, B. Corrigan and J. Fitzgerald, "Utilization-focused integrative reviews in a nursing service," Applied Nursing Research, vol. 11, no. 4, pp. 195-206, 1998.

[12] E. S. Ursi and C. M. Galvão, "Perioperative prevention of skin injury: an integrative literature review," Revista Latino-Americana de Enfermagem, vol. 14, no. 1, pp. 124, 2006.

[13] C. Bailey, R. Murphy and D. Porock, "Dying care in emergency place: caring for the dying in emergency departments," Social Science and Medicine, vol. 73, pp. 1371-1377, 2011a.

[14] C. Bailey, R. Murphy and D. Porock, "Trajectories of end-of-life care in the emergency department," Annals of Emergency Medicine, vol. 57, pp. 362-369, 2011b

[15] C. Bailey, R. Murphy and D. Porock, "Professional tears: developing emotional intelligence around death and dying in emergency work," Journal of Clinical Nursing, vol. 20, pp. 3364-3372, $2011 \mathrm{c}$.

[16] R. L. Beckstrand, V. C. Giles, K. E. Luthy, L. C. Callister and S. Heaston, "The last frontier: rural emergency nurses' perceptions of end-of-life care obstacles," Journal of Emergency Nursing, vol. 38, pp. e15-25, 2012a.

[17] R. L. Beckstrand, V. C. Giles, K. E. Luthy, L. C. Callister and S. Heaston, "Emergency nurses' perception of department design as an obstacle to providing end-of-life care," Journal of Emergency Nursing, vol. 38, pp. e27-32, 2012 b.

[18] R. L. Beckstrand, V. C. Giles, K. E. Luthy, L. C. Callister and S. Heaston, "Emergency nurses' suggestions for improving end-of-life obstacles," Journal of Emergency Nursing, vol. 38, pp. e7-14, 2012c.

[19] R. L. Beckstrand, M. D. Smith, S. Heaston and A. E. Bone, "Emergency nurses' perceptions of size, frequency, and magnitude of obstacles and supportive behaviors in end-of-life care," Journal of Emergency Nursing, vol. 34, pp. 290-300, 2008. 
[20] G. K. Chan, "Trajectories of approaching death in the emergency department: clinician narratives of patient transitions to the end of life," Journal of Pain and Symptom Management, vol. 42, pp. 864-881, 2011.

[21] K. Decker, S. Lee and A. Morphet, "The experiences of emergency nurses in providing end-of-life care to patients in the emergency department," Australasian Emergency Nursing Journal, vol. 18, pp. 68-74, 2015.

[22] S. Heaston, R. L. Beckstrand, E. Bond and S. P. Paimer, "Emergency nurses' perceptions of obstacles and supportive behaviors in end-of-life care," Journal of Emergency Nursing, vol. 32, pp. 477-485, 2006.

[23] K. M. Ho, "Resuscitation versus end-of-life care: Exploring the obstacles and supportive behaviors to providing end-of-life care as perceived by emergency nurses after implementing the end-of-life care pathway," Applied Nursing Research, vol. 29, pp. 7-13, 2016.

[24] A. Jackson, J. Purkis, E. Burnham, G. L. Hundt and L. Blaxter L, "Views of relatives, carers and staff on end of life care pathways," Emergency Nurse, vol. 17, pp. 22-26, 2010.

[25] L. M. Jacobs, K. J. Burns and B. B. Jacobs, "Nurse and physician preferences for end-of-life care for trauma patients," The Journal of Trauma, vol. 69, pp. 1567-1573, 2010.

[26] G. A., Jelinek, C. H. Marck, T. J. Weiland, J. Philip, M. Boughey, J. Weil and H. Lane, "Caught in the middle: tensions around the emergency department care of people with advanced cancer," Emergency Medicine Australasia, vol. 25, pp. 154-160, 2013.

[27] G. A. Jelinek, M. Boughey, C. H. Marck, J. Phillip, J. Weil, H. Lane and T. J. Weiland, "Better pathways of care: suggested improvements to the emergency department management of people with advanced cancer," Journal of Palliative Care, vol. 30, no. 2, pp. 83, 2014.

[28] H. Lane, J. Weil, G. A. Jelinek, M. Boughey, C. H. Marck, T. J. Weiland and J. Philip, "Ideal care and the realities of practice; interdisciplinary relationships in management of advanced cancer patients in Australian emergency department," Supportive Care in Cancer, vol. 22, pp. 10291035, 2014.

[29] C. H. Marck, "Care of the dying cancer patient in the emergency department: findings from a National survey of Australian emergency department clinicians," Internal Medicine Journal, vol. 44, pp. 362-368, 2014.

[30] A. Russ, D. Mountain, I. R. Rogers, F. Shearer, L. Monterosso, G. RossAdjie and J. R. Rogers, "Staff perceptions of palliative care in a public Australian, metropolitan emergency department," Emergency Medicine Australasia, vol. 27, pp. 287-294, 2015.

[31] F. M. Shearer, I. R. Rogers, L. Monterosso, G. Ross-Adjie and J. R. Rogers, "Understanding emergency department staff needs and perceptions in the provision of palliative care," Emergency Medicine Australasia, vol. 26, pp. 249-255, 2014.

[32] A. K. Smith, J. Fisher, M. A. Schonberg, D. J. Pallin, S. D. Block, L. Forrow, R. S. Philips and E. P. McCarthy, "Am I doing the right thing? Provider perspectives on improving palliative care in the emergency department”, Annals of Emergency Medicine, vol. 54, pp. 86-93, 2009.

[33] J. W. K. Tse, M. S. Y. Hung and S. M. C. Pang, "Emergency nurses' perceptions of providing end-of-life care in a Hong Kong emergency department: a qualitative study," Journal of Emergency Nursing, vol. 42, no. 3, pp. 224-232, 2016.

[34] T. J. Weiland, H. Lane, G. A. Jelinek, C. H. March, M. Boughey and J. Philip, "Managing the advanced patient in the Australian emergency department environment: findings from a national survey of emergency department clinician," International Journal of Emergency Medicine, vol. 8, pp. 1-10, 2015.

[35] J. Weil, T. J. Weiland, H. Lane, G. A. Jelinek, M. Boughey, C. H. Marck and J. Philip, "What's in a name? a qualitative exploration of what is understood by "palliative care" in the emergency department," Palliative Medicine, vol. 29, pp. 293-301, 2015. 